\title{
Impact of Emotional and Practical benefits on Green Brand Loyalty; the mediating role of Green Brand Image
}

\author{
${ }^{1}$ Dr. Irfan Hameed, ${ }^{2}$ Nobel Ashley George \\ ${ }^{1}$ Associate Professor, Faculty of Business Administration, Iqra University \\ ${ }^{2}$ Research Scholar, Faculty of Business Administration, Iqra University
}

\begin{abstract}
Natural concerns have driven shoppers to buy items and administrations that are green. This may too incorporate obtaining items from the firms that carry the method of creation with green homes. The reason of this paper is to explore the characteristics of green brands, its picture, and the benefits in regards with its significance to affect buyer discernment. Besides, the inquire about points to examine passionate and viable benefits advertised to shoppers by green brand which afterward impacts consumers' buy eagerly. The inquire about address of this ponder is to investigate green brand benefits and its effect on the brand devotion. It incorporates investigating the effect of commonsense and passionate benefits on the green brand picture and the way green picture is related with brand devotion. In arrange to do so, inquire about has utilized quantitative approach utilizing closed-ended overview survey with a test measure of 100 people. The test measure is chosen with the non-random examining me.
\end{abstract}

\section{Chapter 1: Introduction}

\subsection{Background}

The recent era has been marked as the one with heightened sense of awareness of issues that concern the environment and surroundings. Issues like sustainability and global warming are the primary concern for most of the businesses as well as the consumer base across the world. According to the research of Meise (2014) consumers are now informed about environmental changes more than ever. Hence, consumers are willing to contribute and pay higher cost for services and products they choose, given that they receive perceived return in form of environmental protection, social responsibility, and sustainability (Parsa 2015). In expansion to this, the concept of green promoting alludes to the advancement of thoughts concerning green picture, counting administrations and merchandise and their utilization. According to the research of Ottman (2017) it also includes promoting the concept of protecting the environment which has been a great concern for industrial communities and researchers of sustainable development.

It has been further observed in the research of Buil Martinez and De Chernatony (2013) that organizations tend to exercise more on connecting with their consumers about the efforts they put in making their products and services green. According to Berrone (2013), these efforts include creating trademarks, using green labels, and focusing most on the innovations that are based on green activities. However, there are not many organizations that can successfully create their green brand image and shape the consumer perception positively towards the brand. In most of the times, the failure to build a green image accounts due to the lack of communication between organizations and their consumers (Huang \& Chen 2015). Therefore, the aim of this paper is to evaluate the benefits extracted from becoming a green brand and investigate its influence on brand loyalty through consumer perception.

\subsection{Problem Statement}

There are various studies in literature like Pappu and Quester (2016) and Sen, Du and Bhattacharya (2016) that has debated on the subject of green brand image and consumer perception. The research of Gao and Mattila (2014) suggests that emotional benefits include self-expressive benefits, familiarity and natural experiences alongside

(C) 2019, IJSMS 
utilitarian benefits that help organizations to position themselves as green brands. On the other hand, the findings of Ham and Han (2013) indicate that benefits that promote self-expressiveness tend to project no relationship that is directly involved with the attitude of brand. In addition to this, it has been found in the research of Jeong (2014) that emotional benefits tend to impact consumer perception on a greater level in developing the green brand identity of an organization, contributing to the greater perception. Hence, it can be said that considering the notion of green brand, there has been a significant research gap concerning emotional and functional benefits that are associated with green brand image and its development over a certain period of time, as highlighted in the research of $\operatorname{Ottman}(2017)$.

The main problem that was identified in this research was to estimate the benefits extracted from becoming a green brand and to investigate its influence on brand loyalty through consumer perception in developing countries like Pakistan.

\subsection{Purpose of study:}

The purpose of this research is to investigate and explore the formation of green brand image and its significance in regards to the consumer perception. The customer discernment examined in this research is based on enthusiastic as well as utilitarian benefits that are joined in creating green brands. In addition to this, the purpose of this paper is to investigate the influence green brand image has on purchase behavioral response of the consumers.

\subsection{Research Questions}

The research question of this study is to explore green brand benefits and its influence on brand loyalty. In order to do so, the following research questions are required to produce results:

Question 1: What is the influence of Practical benefits on green brand image?

Question 2: What is the influence of Emotional benefits on green brand image?

Question 3: How Green image is positively associated with brand loyalty

\subsection{Significance of the Project}

The research can be deemed most significant for all organizations as the recent global trends indicate a rise in demand for green activities. The findings of this research can help different organizations to align their strategy based on the elements discovered in establishing a green brand image. In addition to this, understanding the value benefit of associated green brand image with the organization can help it shape the consumer perception and attract them towards its product. Moreover, the findings of this research would also contribute in bridging the communication gap between organizations and consumers towards the green brand image transformation. Lastly, complying with the standards of green would increase the value and credibility of organization with reduced impact on the environment, contributing most in attaining the competitive advantage over rival companies.

\section{Literature Review}

\subsection{MBA Disciplined Area}

Given the area of my MBA discipline area is marketing, there are many different benefits that can be extracted through the findings of this research. The research project will help me understand the core ideology and attitude towards establishing the green brand image, and the way it affects consumer perception. It would help me in analyzing the consumer interaction that is associated with the product offered by the company. On the other hand, the literature included in this research includes approaches that develops green brand image for the organization through introducing practices that are eco-friendly. Understanding the impact of green brand image and green marketing would also highlight different approaches to evaluate the perception of consumer. In addition to this, it would help the marketers with ways in which they can communicate their organization's green benefits to the 
environment, was as protection of surroundings and decreased waste. Moreover, promoting the outcome of green practices can attract consumers, workers and investors with similar approach.

\subsection{Review of Literature}

Due to the increased awareness regarding environmentalism across the globe, there is a dire need to understand consumer perception and marketing strategies that concern green products and green services. It has been observed in various studies that consumers are willing to pay extra cost for the products and services of green nature. Therefore, it is essential for the organizations to formulate its green brand image and market their products through green marketing approaches. In addition to this, companies can opt for these measures to increase the competitive advantage, comply with the pressure of environmentalism, and to seek different markets and opportunities in the global market. It implies that green marketing tactics for the organizations can significantly increase the brand equities that are intangible.

The literature review section of this paper would cover the basic concepts of brand image, green brand image, green marketing, and green brand loyalty. In addition to this, the relationship between green marketing with brand image of an organization is discussed in detail to understand the approach that can be adapted to attract consumers. On the other hand, the literature review section covers the advantageous and implications of green brand image and its relationship with green brand loyalty that consumers of similar mindset project. All of these elements have been found to be interlinked with each other, therefore, the study discusses it in the light of findings concluded by various researchers such as Namkung and Jang (2013) and Sasmita and Mohd Suki (2015).

\subsection{Green Marketing and Brand Image}

Green Marketing can be defined as the way to market eco-friendly services or products, which includes the modification of certain elements, such as packaging, production, advertising, and the way it is communicated to the consumers and amongst peers. There are many different areas in which a green product is offered to the targeted consumers. According to the research of $\mathrm{Ng}(2014)$ ecological marketing and environmental marketing are the two terms used for the same notion as green marketing. The concept of green marketing can be considered as the new approach of marketing that organizations use to promote their environment-friendly products and to lower the negative impact of product distribution and production process on environment. Based on the research of Gao and Mattila (2014) there are essentially 4 elements, namely 4Ps, on which the marketing process relies heavily. These elements are promotion, place, product and price, which can be modified accordingly with the environment friendly services and products to amply protection of environment.

According to the research of Berrone (2013) the concept of green marketing is referred to as the one that is efficient to reestablish the brand image of the organization. It has been noted in the research of Jeong (2014) that good image of an organization play significant role in shaping the perception of consumers towards the product offered. According to the research of Huang and Chen (2015) brand image can be considered as the perception a consumer holds towards the product that has been built in their memories. The research of Namkung and Jang (2013) indicates that green marketing variables could be based on two different elements: green pricing and green product. Furthermore, the research of Meise (2014) suggests that positive brand image contribute in improving the perception of consumer towards the organization or the product, and hence, can influence the purchase decision of consumers. Brand image is significant for the brand development itself as it is considered as a reflection of credibility or reputation the organization has that its consumers can rely on. Customers tend to create choices based on the notoriety of the organization and their past encounters with the same, which is likely to affect their buy choice emphatically or adversely.

In most of the cases, consumers tend to seek information about the product they are about to purchase, which include details about product's brand, location, price and product quality. Based on the research of He and Lai (2014) the purchase process of consumers are mostly based on the purchase decision and purchase intentions. 
Purchase decision is based on the situational factors, while the purchase intention can be based on the attitude of consumers. However, the research of Berrone (2013) indicates that green marketing can influence the purchase intention of product significantly. Furthermore, it has been observed in the research of Chang \& Chen (2014) that consumers prefer products that are promoted through green marketing.

\subsection{Green Brand Image and Green Brand Loyalty}

Green brand image is defined as a broad spectrum that accumulates apprehension, conceptions and impressions that a consumer has towards a specific brand, which promotes eco-friendly activities and sustainability of environment. According to the research of Chen and Chang (2013) consumer's mental image about a brand or product is also referred as the brand image that it has towards the company. In addition to this, brand image is classified as the essence of service or product that is communicated to the consumers that inflict an opinion in their thought process and while making decision of purchase. It has been observed in the research of He \& Lai (2014) that the green brand image is most beneficial in creating awareness of the environmental concerns, through which the organizations can achieve competitive advantage. Moreover, green marketing is associated with the establishment of positive brand image for products that are also environment friendly and green. Understanding these concepts can reflect on the intention of consumers towards purchasing the green products.

Based on the findings of Sen, Du and Bhattacharya (2016) green brand image can be taken as the choice of consumers for green products. Positive image and reputation of the organization influences the purchase intention of consumers positively to make use of green products. Hence, the success of any organization can be evaluated through the number of accumulated consumers and the loyalty of these consumers towards the products. Increasing the loyal consumer base is one of the most effective strategies of marketing and establishing green brand image of an organization.

According to the research of Ottman (2017) consumers are likely to purchase goods that have high reputation in the market, which implies that higher brand image and reputation of the product is likely to attract more consumers. Therefore, it can be observed that positive brand image has a positive relation with green brand loyalty, behavior, decision and purchasing decisions of consumers. Furthermore, brand loyalty has been termed as commitment of a consumer according to the research of Ham \& Han (2013). The concept of brand loyalty is even more intense in the markets where competition is high between different brands of similar kinds.

Considering the notion of green marketing, organizations can enhance their position in the competitive market through complying with environmental demands and to satisfy consumers that are loyal to green products as well. These consumers can be allured through different green marketing strategies, as highlighted in the research of Chan (2013). On the other hand, green position of brands or products is likely to enhance the awareness regarding environmental concerns, which later impacts the intention of consumers in purchasing. It has been argued upon in the research of Gao and Mattila (2014) that the attitude and behavior related to green loyalty is derived through the behavioral and emotional aspect of purchasing decisions. It further increases the willingness and readiness of consumers to pay higher cost for the product. The research of Jeong (2014) focuses on the relationship between green branding and brand loyalty, satisfaction and trust of consumers. On the other hand, the research of Chang \& Chen (2014) and He \& Lai (2014) emphasized the concept of brand image as a vital element that promotes brand loyalty of consumer. It is found to bemore specific and significant in the context of green brand image and loyalty.

\subsection{Hypotheses}

H1: Practical benefits positively influence green brand image

$\mathrm{H} 2$ : Emotional benefits positively influence green brand image

H3: Green image is positively associated with brand loyalty 


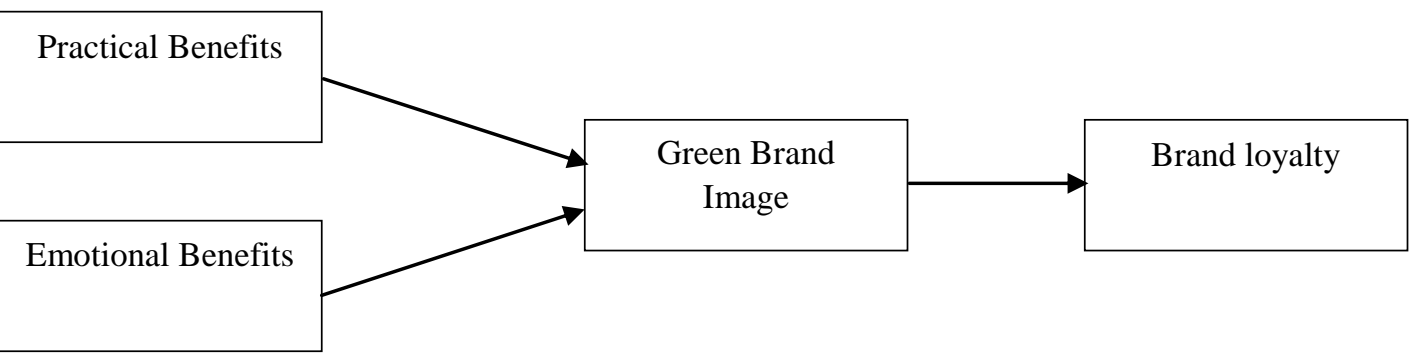

Hypothesized Model

\section{Research Methods}

Research methods, which is the third chapter of this research project reflects on the methods and techniques deployed in the context of this research. It includes the descriptions of methodology along with the research approach of the project. It highlights the tools used to progress the research process of this study. In addition to this, the chapter also includes the sample population size and ways that confirm validity and reliability of the research. Lastly, the chapter concludes by illustrating data analysis techniques, ethical consideration and schedule of completion.

\subsection{Methodology}

Methodology is divided into two broad research methods, which are secondary and primary. The primary research methods are considered to be the ones that are used in specific research with definite purposes. In comparison with the secondary research methods, primary methods of research are found to be most expensive and consume ample amount of time for the specificity and completion of tasks. However, the data obtained through primary research include various respondents and accuracy of results (Nardi, 2018). Selective form of primary method of research includes partial study that involves only a specific portion of respondents for drawing conclusions. Therefore, the research was based on the collection of data through primary methods.

\subsection{Research Approach}

Deductive approach was found to be the most appropriate approach in regards with this research.

\subsubsection{Quantitative Research}

The research is based on quantitative approach, According to the research of Creswell and Creswell (2017), quantitative research methods are effective in providing information that can be statistically presented. The research through quantitative methods includes hall tests, interviews, and other methods such as survey questionnaires as well. For the purpose of this research, quantitative method of approach was used with the tool of survey questionnaire.

\subsection{Data Collection}

The data collection used for this research was primary data. In other words the data collected firsthand by the researcher is called primary data. The survey questionnaire was based on close ended questions that were required to be responded by participants. There was total number of 100 questions included in the survey, which facilitated the researcher with information for analysis. The most considerable aspect of using quantitative data for the research is its ability to run tests and analysis on software of larger data with lesser complexities. 


\subsubsection{Instrument of Data Collection}

The instrument of data collection was a survey questionnaire that is based on closed-ended questions. It is further arranged in the form of Likert scale to ensure that it is easily comprehended by the participants. The results obtained from these participants are further analyzed and interpreted statistically. The participants were required to fill the questionnaire on the basis of their observation and personal views on statements.

\subsection{Sampling Design}

Non-random sampling methods had deployed in this research to sample the information obtained. It implies that all elements of the research are equally directed to contribute in the results because of their equal impact on the probability of results.

\subsubsection{Sample Size}

Sample size for this research was 100 participants who were given the questionnaire to obtain results.

\subsection{Statistical Technique}

The data was analyzed through inferential statistical technique for this research.

\subsection{Ethical Consideration}

Ethical consideration is referred to as the considerations taken against all risks attached possibly with the research. For this research, each and every aspect of ethical considerations is taken into account. Since the research is conducted through primary methods, therefore, the participants are given consent forms that they are required to fill and acknowledge with the specifics laid out in the context of this research. However, the anonymity of participants are ensured and communicated along with the assurance of information to be used specifically for this particular research only.

\section{Results}

\subsection{Analyzing the data}

The following data was obtained through primary data with the help of close ended questionnaire which was based on likert scale. The data analyzed the green brand benefits impact on brand loyalty. The data was first analyzed through regression then by correlation method in order to obtain the results.

\section{Model Summary}

\begin{tabular}{|l|l|l|l|l|}
\hline Model & $\mathrm{R}$ & R Square & Adjusted R Square & $\begin{array}{l}\text { td. Error of the } \\
\text { Estimate }\end{array}$ \\
\hline 1 & $.815^{\mathrm{a}}$ & .664 & .660 & 1.98200 \\
\hline
\end{tabular}

a. Predictors: (Constant), Self_expressive_benefits, Utilitarian_benefits

The simple correlation displays the $\mathrm{R}$ value which is $81 \%$ that identifies a correlation between variable which is of high degree means green brand benefits does impact brand image.

\section{ANOVA $^{\mathrm{b}}$}

\begin{tabular}{|ll|l|l|l|l|l|}
\hline Model & & Sum of Squares & df & Mean Square & F & Sig. \\
\hline 1 & Regression & 1149.707 & 2 & 574.854 & 146.336 & $.000^{\mathrm{a}}$ \\
& Residual & 581.392 & 148 & 3.928 & & \\
& Total & 1731.099 & 150 & & & \\
\hline
\end{tabular}

a. Predictors: (Constant), Self_expressive_benefits, Utilitarian_benefits

b. Dependent Variable: Green_brand_image 
It was discover from ANOVA that sig value is $(<0.05)$ that identifies level of significance and this is actually the linear relationship between variables and the model is significant for further analysis. Whereas model is absolutely fit from the value of $\mathrm{F}$ which indicate excellent fitness since it value was 146.336 .

\subsection{Answering the research questions}

Coefficients $^{\mathrm{a}}$

\begin{tabular}{|c|c|c|c|c|c|c|}
\hline \multirow{2}{*}{\multicolumn{2}{|c|}{ Model }} & \multicolumn{2}{|c|}{ Unstandardized Coefficients } & \multirow{2}{*}{\begin{tabular}{|l} 
Standardized \\
Coefficients
\end{tabular}} & \multirow[b]{2}{*}{$\mathrm{t}$} & \multirow[b]{2}{*}{ Sig. } \\
\hline & & B & Std. Error & & & \\
\hline \multirow[t]{3}{*}{1} & (Constant) & 1.346 & .835 & & 1.612 & .109 \\
\hline & Utilitarian_benefits & .549 & .082 & .413 & 6.726 & .000 \\
\hline & Self_expressive_benefits & .481 & .060 & .489 & 7.957 & .000 \\
\hline
\end{tabular}

a. Dependent Variable: Green_brand_image

The table of coefficient summarize each hypotheses acceptance or rejection so from the analysis utilitarian benefits and self expressive benefits both were accepted since their sig value is $(<0.05)$ which points toward acceptance and also both the variables has positive impact since $\mathrm{T}$ value is in positive.

\section{Green brand image on brnnd loyalty}

\section{Correlations}

\begin{tabular}{|ll|l|l|}
\hline & & Green_brand_image & Brand_loyalty \\
\hline Green_brand_image & Pearson Correlation & 1 & $.606^{* *}$ \\
& Sig. (2-tailed) & 151 & .000 \\
& $\mathrm{~N}$ & $.606^{* *}$ & 151 \\
\hline Brand_loyalty & Pearson Correlation & .000 & 1 \\
& Sig. (2-tailed) & 151 & 151 \\
& $\mathrm{~N}$ & & 1 \\
\hline
\end{tabular}

**. Correlation is significant at the 0.01 level (2-tailed).

The table of correlation shows the result of the analysis. Green brand image (correlation coefficient value 606 were found positively correlated with dependent variable brand loyalty.

\subsection{Hypotheses assessment summary}

\begin{tabular}{|l|l|l|l|}
\hline S.no & & Sig-value & Empirical Result \\
\hline H1 & $\begin{array}{l}\text { Practical benefits positively influence green brand } \\
\text { image }\end{array}$ & .000 & Accepted \\
\hline H2 & $\begin{array}{l}\text { Emotional benefits positively influence green brand } \\
\text { image }\end{array}$ & .000 & Accepted \\
\hline H3 & Green image is positively associated with brand loyalty & .000 & Accepted \\
\hline
\end{tabular}




\section{Conclusion, Discussion, Implications, and Discussions}

\subsection{Conclusion}

The research concludes that the benefits attached with green brand have significant and positive relationship with the brand loyalty. It has been found through the research that consumers are influenced by the practical as well as emotional benefits that are received through purchasing green products and services. Therefore, it is found that emotional and practical benefits of purchasing green products are positively associated with green brand image. These benefits include high quality of products, environmental benefits, better health outcomes, and benevolent impact such as moral satisfaction. These benefits collaboratively impact the satisfaction level of consumers, which increases their will to repurchase items from the same brand. In this way, it increments the brand devotion of buyers towards green brand. The research also indicates that the notion of green brand is associated with not only the products, but also the practices carried out to manufacture or produce the said products. Moreover, items that are manufactured or produced using green practices are considered environment friendly, which impact consumers' repurchasing intensions. In this manner, customers are slanted to pay indeed more cash to purchase items that does not hurt environment for them.

\subsection{Discussion}

\section{H1. Practical benefits positively influence green brand image}

Based on the findings of this research, the hypothesis indicating that practical benefits have positive influence on green brand image and is accepted. It is aligned with the research of Sasmita and Mohd Suki (2015), which indicates that consumer, tends to purchase goods that have functional value in accordance with their expectations. These expectations are associated with the quality of the product and the way these things have been processed. In accordance with the research of Chen et al (2017), consumer perception of green products suggest value for money that contributes in the betterment of environment in a long term, hence, yielding high quality. According to the research of Bekk et al (2016) consumers are willing to pay high price for goods that they perceive are manufactured with green practices because of their high quality.

H2. Emotional benefits positively influence green brand image

The findings of this research accept the hypothesis that emotional benefits have a positive impact on green brand image. It has been found in the research of Lim, Lobo and Lecki (2017) consumer tends to purchase green products as it satisfies their ego through contributing benefits to the environment. The notion of self-sacrifice or altruism enhances the motivation of consumers to opt for products that perform green practices and offer green products. In addition to this, the research of Jang, Kim and Lee (2015) concludes that the moral satisfaction leads the consumers to purchase products from green brands. It is also linked with the self-esteem and constant need for social expression of consumers has positively influenced the green brand image, as highlighted in the research of Chang and Chen (2014) Similarly, the research of Gao and Mattila (2014) indicates that consumer tend to opt for brands that help them achieve personal satisfaction.

H3. Green image is positively associated with brand loyalty

The research accepts the hypothesis that green image has a positive influence on brand loyalty. It has been linked with the research of Huang and Chen (2015) that suggests loyalty with green brands is associated with the commitment of consumers towards improving the environment. It has been noted in the research of Meise et al (2014) that concerns regarding environmentalism attract consumers to buy green brands that further enhances the

(C) 2019, IJSMS 
warm glow benefit. In addition to this, the research of Pappu and Quester (2016) suggests that green satisfaction, green trust, and the green image are a few contributing factors that enriches brand loyalty of consumers towards green products.

\subsection{Implications}

The findings of this research imply that consumer loyalty is associated with the perceived value of goods and services they purchase. As found in the results, consumers are likely to purchase products/services that gives them value to their money, which can either be emotional or practical. While practical benefits of the green products are associated with the high quality \& moral satisfaction experienced by consumers are the most influential elements for brand loyalty. It also implies that the value of each product is based on the benefits it provides to its consumers, which can be either emotional or practical.

\subsection{Recommendations}

It is recommended for the future researchers to ensure that multiple other attributes of brand loyalty are discussed considering various industries. In addition to this, it is recommended for the organizations to understand the importance of consumer satisfaction and perceived value of goods in order to attract them. Understanding the perceived value consumer has in regards with the green products, green practices, and green initiatives is likely to favor organizations with green benefits. It is also recommended for the decision makers to understand and enhance benevolent benefits green products offer to consumers in order to impact their buying behavior.

\section{References}

[1] Berrone, P., Fosfuri, A., Gelabert, L., \& Gomez-Mejia, L. R. (2013). Necessity as the mother of 'green' inventions: Institutional pressures and environmental innovations. Strategic Management Journal, 34(8), 891-909.

[2] Buil, I., Martínez, E., \& De Chernatony, L. (2013). The influence of brand equity on consumer responses. Journal of consumer marketing,. Does environmental information disclosure benefit waste discharge reduction? Evidence from China.30(1), 62-74

[3] Chang, C.H. and Chen, Y.S., (2014). Managing green brand equity: The perspective of perceived risk theory. Quality \& Quantity, 48(3), $1753-1768$

[4] Chen, Y.S. and Chang, C.H., (2013). Greenwash and green trust: The mediation effects of green consumer confusion and green perceived risk. Journal of Business Ethics, 114(3),.489-500.

[5] Gao, Y. L., \&Mattila, A. S. (2014). Improving consumer satisfaction in green hotels: The roles of perceived warmth, perceived competence, and CSR motive. International Journal of Hospitality Management, 42, 20-31.

[6] Ham, S., \& Han, H. (2013). Role of perceived fit with hotels' green practices in the formation of customer loyalty: Impact of environmental concerns. Asia Pacific Journal of Tourism Research, 18(7), 731-748.

[7] Huang, R., \& Chen, D. (2015). Does environmental information disclosure benefit waste discharge reduction? Evidence from China. Journal of business ethics, 129(3), 535-552.

[8] Jeong, E., Jang, S. S., Day, J., \& Ha, S. (2014). The impact of eco-friendly practices on green image and customer attitudes: An investigation in a café setting. International Journal of Hospitality Management, 41, 10-20.

[9] Meise, J. N., Rudolph, T., Kenning, P., \& Phillips, D. M. (2014). Feed them facts: Value perceptions and consumer use of sustainabilityrelated product information. Journal of Retailing and Consumer Services, 21(4), 510-519.

[10] Namkung, Y., \& Jang, S. S. (2013). Effects of restaurant green practices on brand equity formation: Do green practices really matter? International Journal of Hospitality Management, 33, 85-95.

[11] Ng, P. F., Butt, M. M., Khong, K. W., \& Ong, F. S. (2014). Antecedents of green brand equity: An integrated approach. Journal of Business Ethics, 121(2), 203-215.

(C) 2019, IJSMS

Page 17 
[12] Ottman, J. (2017). The new rules of green marketing: Strategies, tools, and inspiration for sustainable branding. Routledge.

[13] Pappu, R., \& Quester, P. G. (2016). How does brand innovativeness affect brand loyalty? European Journal of Marketing, 50(1/2), 2-28.

[14] Sasmita, J., \&Mohd Suki, N. (2015). Young consumers' insights on brand equity: Effects of brand association, brand loyalty, brand awareness, and brand image. International Journal of Retail \& Distribution Management, 43(3), 276-292.

[15] Sen, S., Du, S., \& Bhattacharya, C. B. (2016). Corporate social responsibility: a consumer psychology perspective. Current Opinion in Psychology, 10, 70-75.

[16] Bekk, M., Spörrle, M., Hedjasie, R. and Kerschreiter, R., 2016. Greening the competitive advantage: antecedents and consequences of green brand equity. Quality \& Quantity, 50(4), pp.1727-1746.

[17] Chang, C.H. and Chen, Y.S., (2014). Managing green brand equity: The perspective of perceived risk theory. Quality \& Quantity, 48(3), 1753-1768.

[18] Chen, Y.S., Hung, S.T., Wang, T.Y., Huang, A.F. and Liao, Y.W., 2017. The influence of excessive product packaging on green brand attachment: The mediation roles of green brand attitude and green brand image. Sustainability, 9(4), p.654.

[19] Gao, Y. L., \&Mattila, A. S. (2014). Improving consumer satisfaction in green hotels: The roles of perceived warmth, perceived competence, and CSR motive. International Journal of Hospitality Management, 42, 20-31.

[20] Huang, R., \& Chen, D. (2015). Does environmental information disclosure benefit waste discharge reduction? Evidence from China. Journal of business ethics, 129(3), 535-552.

[21] Jang, Y.J., Kim, W.G. and Lee, H.Y., 2015. Coffee shop consumers' emotional attachment and loyalty to green stores: The moderating role of green consciousness. International Journal of Hospitality Management, 44, pp.146-156.

[22] Jeong, E., Jang, S. S., Day, J., \& Ha, S. (2014). The impact of eco-friendly practices on green image and customer attitudes: An investigation in a café setting. International Journal of Hospitality Management, 41, 10-20.

[23] Lin, J., Lobo, A. and Leckie, C., 2017. Green brand benefits and their influence on brand loyalty. Marketing Intelligence \& Planning, 35(3), pp.425-440.

[24] Meise, J. N., Rudolph, T., Kenning, P., \& Phillips, D. M. (2014). Feed them facts: Value perceptions and consumer use of sustainabilityrelated product information. Journal of Retailing and Consumer Services, 21(4), 510-519.

[25] Pappu, R., \& Quester, P. G. (2016). How does brand innovativeness affect brand loyalty? European Journal of Marketing, 50(1/2), $2-28$.

[26] Sasmita, J., \&Mohd Suki, N. (2015). Young consumers' insights on brand equity: Effects of brand association, brand loyalty, brand awareness, and brand image. International Journal of Retail \& Distribution Management, 43(3), 276-292. 